\title{
Substitution Effect of Maize (Zea Mays) with Grain Milling By-Products on Egg Production and Hatchability of Eggs in White Leghorn Layer Hens
}

\author{
Aberra Melesse \\ School of Animal and Range Sciences, College of Agriculture, Hawassa University \\ P. O. Box 05, Hawassa, Ethiopia
}

\begin{abstract}
The substitution effect of maize grain with grain milling by-products (GMP) was investigated on egg production and fertility parameters in White Leghorn layer hens. To this effect, four treatment $(\mathrm{T})$ diets were formulated to contain GMP (g/kg) at zero (T1), 100 (T2), 150 (T3) and 200 (T4) by partially replacing the maize grain. Onehundred forty four White Leghorn layer hens were allocated randomly to the treatment diets, replicated thrice consisting of 12 hens each. The experiment was conducted for 20 weeks. The results indicated that the hen-housed egg production and daily egg mass output was higher $(\mathrm{p}<0.001)$ in hens fed with $\mathrm{T} 1$ and $\mathrm{T} 2$ diets than those of T3 and T4. Birds fed with T1 diet produced heavier $(\mathrm{p}<0.001)$ eggs than those reared in T2, T3 and T4 diets, the former being significantly different with the latter two. The daily feed intake differed significantly among treatment diets being higher $(\mathrm{p}<0.001)$ in birds fed with T1 and T2 than that of T3 and T4 diets, which had similar values. No significant difference was observed in hen-housed egg production, daily egg mass output, and daily feed intake among hens fed with T1 and T2 diets. Similarly, no significance difference was observed in egg weight, total and daily feed intake between hens fed with T3 and T4 diets. The feed conversion ratio (FCR, $\mathrm{kg}$ feed $/ \mathrm{kg}$ egg mass) were different among treatment diets in which the lowest value being observed in those chickens reared in T1 followed by T2 diets. Birds fed with T4 diet had the highest FCR as compared with the rest of the treatment groups. Fertility and hatchability of eggs set were similar among chickens reared in T1 and T2 diets; but were higher $(\mathrm{p}<0.05)$ than those of T3 and T4 which had similar values. However, hens fed with T4 diet had lower $(p<0.05)$ value in hatchability of fertile eggs than the rest of other treatments. In conclusion, the substitution of maize grain with $10 \%$ GMP showed similar effect with that of the control group in all studied performance parameters. Thus, GMP could be safely incorporated in replacement of maize for layer hen diets up to $10 \%$.
\end{abstract}

Keywords: egg fertility; egg production; grain milling by-products; maize grain; White Leghorn chicken

DOI: $10.7176 / \mathrm{JBAH} / 10-9-02$

Publication date:May $31^{\text {st }} 2020$

\section{Introduction}

In most of the rural parts of Africa, poultry plays an important role in improving the nutritional requirement of rural community through consumption of poultry products such as egg and meat. Moreover, it serves as major income generation for most rural women (Melesse 2014). Nevertheless, a dynamic increment in the cost of cereal grains and human competition impose a great challenge on economic viability of the sector coupled with limited accessibility of land to produce maize for poultry feed (Shapiro et al. 2015). With increasing demand for livestock products as a result of rapid growth in the world economies and shrinking land area, future hopes of feeding the animals and safeguarding their food security will depend on the better utilization of other feed resources which do not compete with human food (Melesse et al. 2013, 2019). As a result, searching for cheap and easily accessible plant protein sources for possible inclusion in poultry feeds becomes imperative option to offset the scarcity and high cost of conventional poultry feeds. In this regard, unconventional feeds could partly fill the gap in the feed supply, decrease competition for food between humans and animals, reduce feed cost, and contribute to self-sufficiency in nutrients from locally available feed sources.

Among the unconventional feedstuffs, by-products from cereal grain milling processing plants that have been evaluated for use in livestock and poultry nutrition. The most commonly used cereal grain milling by-products in poultry nutrition are maize bran, wheat bran, and different forms of rice bran (Aliakbarpour et al. 2004; Boros et al. 2004; Maina et al. 2013; Martínez et al. 2015). The nutritional values of the by-products may vary depending upon the types of grains cultivated in a given location. As a result, in the change in proportions of fibrous and nonfibrous carbohydrates, the energy values for the mill feeds are lower than the parent grains. In contrast, the protein contents of the mill feeds are generally higher than the parent grains. (https://courses.ecampus.oregonstate.edu/ans312/two/milling_trans.htm).

In Ethiopia, there are plenty of small-scale local flour millers in many cities of the country, which produce unknown volume of grain milling by-products year round. Most of these by-products are leftovers after milling multiple types of grains. Tef (Eragrostis tef), maize, sorghum, lentils, wheat, barley, peas and chickpeas are the most common multiple grains that are consumed by the community in many places of the study area (personal 
observations). It is thus expected that most of the milling products could be composed of these major grains. They are plentiful, inexpensive and have potential to be successfully incorporated into poultry feeds. This signifies the availability of such useful by-products, which could be used as alternative animal feed resources in the urban and per-urban areas. However, to the author's knowledge, there is no adequate information on the nutritive and feeding values of grain milling by-products as a source of poultry feed in Ethiopia. Thus, this study was designed to investigate the effect of feeding grain-milling by-products as a partial replacement of maize on egg production performances of White Leghorn chickens.

\section{Materials and methods}

\subsection{Describing the experiment site}

The study was conducted at Ella Kebella Women's Association Poultry Farm located at Humbo district in North Omo. The research site is situated in the rift valley at the latitude of $6^{\circ} 39^{\prime}$ North and longitude of $37^{\circ} 49^{\prime}$ East with an altitude of 1450 meters above sea level. The annual rainfall ranges between 460 and $740 \mathrm{~mm}$ with a mean of $670 \mathrm{~mm}$. The mean maximum and minimum temperatures are $28.6^{\circ} \mathrm{C}$ and $20.4^{\circ} \mathrm{C}$, respectively.

\subsection{Preparation of feed ingredients}

The feed ingredients used in the formulation of the experimental rations contain maize, roasted soybean, grain milling by-products (GMP), whole fishmeal, cotton seed cake, limestone and salt. Maize, raw soybean, cotton seed cake, fishmeal, limestone, and salt were purchased from the nearby markets. Grain milling by-products were purchased from nearby small-scale local flour millers. The soybean seed was roasted for 5 minutes to deactivate the trypsin inhibitor (Rocha et al. 2014) and then milled in sieve size of $5 \mathrm{~mm}$ separately. All other feed ingredients were milled with similar sieve size and mixed together. Alfalfa was grown at the backyard of the poultry farm and fresh leaves were provided to all experimental birds ad libitum.

\subsection{Experimental design}

After having results on chemical and mineral analysis of each feed ingredients, four iso-nitrogenous and iso-caloric experimental diets were formulated to contain the control and experimental diets. The control diet (treatment 1, T1) contained no GMP and diets containing GMP at the levels of $100 \mathrm{~g} / \mathrm{kg}$ (treatment 2, T2), $150 \mathrm{~g} / \mathrm{kg}$ (treatment 3, T3) and $200 \mathrm{~g} / \mathrm{kg}$ (treatment 4, T4) by partially substituting the maize in the control diet (Table 1). One hundred and forty four White Leghorn layer hens were distributed according to a completely randomized experimental design into 4 treatment diets with 3 replicates of 12 birds each.

Table 1. Experimental design of the feeding trial with White Leghorn layer hens

\begin{tabular}{ccccccc}
\hline $\begin{array}{l}\text { Treatment } \\
\text { diets }\end{array}$ & $\begin{array}{l}\text { Substitution level of maize } \\
\text { with GMP }(\mathrm{g} / \mathrm{kg})\end{array}$ & $\begin{array}{l}\text { Number of } \\
\text { replicates }\end{array}$ & $\begin{array}{l}\text { Hens } \\
\text { replicate }\end{array}$ & $\begin{array}{l}\text { per } \\
\text { diets }\end{array}$ & $\begin{array}{l}\text { pers } \\
\text { T1 }\end{array}$ \\
\hline T2 & 0 & 3 & 12 & 12 & 36 \\
T3 & 100 & 3 & 12 & 36 \\
T4 & 150 & 3 & 12 & 36 \\
Total $(\mathrm{N})$ & 200 & 3 & & 36 \\
\hline
\end{tabular}

\subsection{Management of chickens}

Before the arrival of experimental birds, pens, drinkers, and feeders were properly cleaned and disinfected. Two hundred and forty White Leghorn pullets and 40 cocks were obtained from the College of Agriculture of Hawassa University and transported to the poultry house. The concrete floor of the poultry house was covered with wood shavings at a depth of about $5 \mathrm{~cm}$. Natural lighting system, which was relatively constant over 12 hours per day, was used. This was provided through open sides of the house and chicken wire mesh in place. The open sides also provided adequate ventilation.

All chickens were vaccinated against major poultry viral and bacterial diseases including Marek's disease, Newcastle, infectious bursal disease (Gumboro), fowl typhoid and fowl pox diseases. After arrival at the experimental site, pullets were leg-tagged, weighed and randomly distributed to the pre-prepared experimental pens with a dimension of $3 \mathrm{~m}^{2}(2 \times 1.5 \mathrm{~m})$ per replicate. The pullets were fed with pullet commercial rations until the age of 19 weeks. They were then fed with the formulated experimental rations starting from the 19th weeks of age until end of the experiment (Table 2). Feeds were provided to all birds in the form of concentrate. Clean fresh water was provided ad libitum throughout the experimental period. Feeders and drinkers were cleaned daily to remove contamination from feed particles and the litter. Similar management conditions (light, temperature, and ventilation) were provided to all birds throughout the experimental period. 
Table 2. Feed ingredients (g/kg) and nutrient compositions (g/kg DM) of the control diet and diets containing different levels of grain milling by-products of the layer ration

\begin{tabular}{lllll}
\hline Feed ingredients & $\mathrm{T} 1$ & $\mathrm{~T} 2$ & $\mathrm{~T} 3$ & $\mathrm{~T} 4$ \\
\hline Maize & 650 & 550 & 500 & 450 \\
Soybean seed (roasted) & 170 & 165 & 175 & 170 \\
Grain milling products & 0 & 100 & 150 & 200 \\
Cotton seed cake & 65 & 70 & 70 & 70 \\
Fish meal & 45 & 35 & 25 & 25 \\
Limestone & 65 & 75 & 75 & 80 \\
Common salt & 5 & 5 & 5 & 5 \\
Alfalfa (green leaf) & Ad libitum & Ad libitum & Ad libitum & Ad libitum \\
Total & 1000 & 1000 & 1000 & 1000 \\
Calculated values (g/kg) & & & & \\
ME (kcal/kg DM) & 2702 & 2791 & 2771 & 2741 \\
Ash & 31.4 & 40.5 & 57.7 & 30.0 \\
Crude protein & 173 & 180 & 183 & 187 \\
Crude fiber & 51.9 & 59.5 & 64.2 & 67.7 \\
Crude fat & 101 & 90.3 & 85.2 & 80.7 \\
Calcium & 27.8 & 30.9 & 30.3 & 32.2 \\
Phosphorous & 4.80 & 4.70 & 4.50 & 4.60 \\
\hline
\end{tabular}

\subsection{Data collection protocols}

\subsubsection{Feed intake and egg production}

Chickens were fed on replicate basis and each day a measured amount of feed was offered in the morning (between 7.00 and $8.00 \mathrm{am}$ ) and late afternoon (between 5.00 and $6.00 \mathrm{pm}$ ) and feed refusals were collected and weighed in the morning of the following day before feed is offered. Feed intake on replicate basis was then computed by subtracting the feed refusal from that of feed offered. Eggs were collected daily and egg production rate was calculated on henhoused basis by considering the number of hens that were housed initially. Egg weight was determined on biweekly basis and the average egg weight was calculated. Total egg mass was computed by multiplying the average egg weight with total number of eggs produced per hen. Daily egg mass per hens was computed through dividing the total egg mass by the number of hens that were initially housed and total number of days in which the hens were in lay. Feed conversion ratio was calculated as a ratio of $\mathrm{kg}$ feed to $\mathrm{kg}$ egg mass output. The duration of the experiment was 150 days.

\subsubsection{Egg fertility and hatchability}

Three weeks before the end of the experiment period, two White Leghorn cocks per replicate were introduced to determine the fertility and hatchability of the eggs. At the end of the experiment, 15 eggs were collected for three consecutive days from each replicates totaling 180 eggs. The eggs were then placed in an incubator and were candled on the 18th day of incubation. After candling, the number of fertile and unfertile eggs was recorded. Average fertility of eggs was then computed by dividing the total number of eggs found fertile after candling with the total number of eggs set. Hatchability was then obtained from hatchability of fertile eggs and hatchability of eggs set. Accordingly, hatchability of eggs set for incubation was determined by dividing the total number of chicks hatched with that of total eggs set. Hatchability of fertile eggs was computed by dividing the number of chicks hatched to the number of fertile eggs after candling. It is would be worthwhile to note that each result was multiplied by 100 to get the percentage values.

\subsection{Chemical analysis}

Analyses of proximate nutrients were performed as outlined by AOAC (2005). Samples of feed ingredients were analyzed for dry matter (DM, method 950.46), ether extract (EE, method 920.39), crude fibre (CF, method 962.09) and ash (method 942.05). Neutral detergent fiber (NDF) was analyzed using the method of Van Soest et al. (1991) in an ANKOM ${ }^{\circledR} 200$ Fiber Analyzer (ANKOM Technology Corp., Fairport, NY, USA). The crude protein (CP) was assessed using Kjeldahl procedure (method 954.01) and the nitrogen content was multiplied by 6.25 to obtain the CP. Calcium (Ca) was determined by atomic absorption spectrophotometer and phosphorus (P) by colorimetrically methods as described by AOAC (2005). The metabolizable energy (ME) of diets was estimated based on the feed composition tables of tropical feeds for poultry. The NDF content of samples of was analyzed at the Nutrition Laboratory of Hawassa University while the other nutrients were analyzed at Holeta Agricultural Research Center, Ethiopia. All samples were analyzed in duplicates in both laboratories.

\subsection{Statistical analysis}

Data on feed intake, body weight, body weight gain, feed conversion ratio, egg weight, hen-housed egg production, 
egg mass output and egg fertility and hatchability parameters were subjected to one-way ANOVA by fitting treatment diets as fixed effects. The ANOVA procedures of Statistical Analysis System (SAS, 2012, ver. 9.4) were used to analyze the collected data and treatment means were compared using Tukey's Studentized Range (HSD) test. Comparisons with $\mathrm{p}<0.05$ were considered as significant. The following statistical model was used to analyze the data: $Y_{i j}=\mu+A_{i}+D_{j} / A_{i}+e_{i j}$, where:

$Y_{i j}=$ observed values of the dependent variables (feed intake, egg production, egg weight, egg mass)

$\mu=$ overall mean of the response variable

$A_{i}=$ the effect of the $i^{i \text { th }}$ grain milling by-products $(i=1,2,3,4)$ on the dependant variables

$\mathrm{D}_{\mathrm{j}} / \mathrm{A}_{\mathrm{i}}=$ the effect of the $\mathrm{j}^{\text {th }}$ replicate $(\mathrm{j}=1,2,3)$ within the level of the $\mathrm{i}^{\text {th }}$ grain milling byproduct

$\mathrm{e}_{\mathrm{ij}}=$ residual error due to random effects

\section{Results}

\subsection{Chemical composition}

Chemical composition analysis of feed ingredients used in this experiment has been presented in Table 3. As expected, the highest ash content was observed in fishmeal followed by alfalfa grass while the least was found in maize and GMP. The CP content was highest in fishmeal followed by cottonseed cake and roasted soybean seed. The analyses further indicated the GMP to be low in fat, high in crude fiber, and moderately high in protein and ash. The fat (EE) content was highest in soybean but lowest in cotton seed cake, which had the highest CF and NDF contents. The highest Ca and $\mathrm{P}$ contents were found in fishmeal.

Table 3. Chemical composition of different feed ingredients used in formulating the treatment diets (g/kg DM)

\begin{tabular}{lllllllll}
\hline Ingredient & Ash & CP & EE & CF & NDF & Ca & P & $\begin{array}{l}\text { ME } \\
(\mathrm{kcal} / \mathrm{kg})\end{array}$ \\
\hline $\begin{array}{l}\text { Maize } \\
\text { Soybean seed (roasted) }\end{array}$ & 16.1 & 100 & 45.0 & 43.0 & 20.3 & 0.50 & 3.00 & 3300 \\
$\begin{array}{l}\text { Grain milling by- } \\
\text { products }\end{array}$ & 20.3 & 212 & 25.6 & 120 & 130 & 0.9 & 6.0 & 2939 \\
Fishmeal & & & & & & & & \\
Cotton seed cake & 227 & 569 & 60.0 & - & - & 63.5 & 34.1 & 2720 \\
Fresh alfalfa grass & 68.6 & 389 & 7.30 & 150 & 390 & 1.80 & 10.8 & 2350 \\
\hline
\end{tabular}

$\mathrm{CP}=$ crude protein; $\mathrm{EE}=$ crude fat; $\mathrm{CF}=$ crude fiber; $\mathrm{NDF}=$ neutral detergent fiber; $\mathrm{Ca}=$ calcium; $\mathrm{P}=$ phosphorous; $\mathrm{ME}=$ metabolizable energy (calculated values)

\subsection{Feed consumption and egg production parameters}

The hen-housed egg production was higher $(p<0.001)$ in hens fed with T1 and T2 than those reared in T3 and T4 diets (Table 4). The total and daily egg mass production followed the same pattern as that of hen-housed egg production being higher $(\mathrm{p}<0.001)$ in birds fed with the T1 and T2 diets than that of T3 and T4. The corresponding values were higher $(p<0.001)$ in chickens fed with T3 than those of T4. Birds fed with T1 had higher $(p<0.001)$ egg weight than those reared in T2, T3 and T4 diets, in which the former being significantly different with the latter two treatment diets. The total and daily feed intake differed significantly among treatment diets being higher $(\mathrm{p}<0.001)$ in birds fed with T1 and T2 than that of T3 and T4 diets, which had similar values. However, no significance difference was observed in hen-housed egg production, egg mass output, and feed intake among hens fed with T1 and T2 diets. Similarly, no significance difference was found in egg weight, feed intake between birds fed with T3 and T4 diets. The FCR values were significantly different among treatment diets in which the lowest value being observed in those chickens reared in T1 followed by T2 diet. Birds fed with T4 had the highest FCR as compared with the rest of the treatment groups.

Table 4. The replacement effect of maize grain with different levels of grain milling by-products on feed intake, egg production, and feed conversion ratio

\begin{tabular}{lccccc}
\hline Parameters & T1 & T2 & T3 & T4 & SEM \\
\hline Hen-housed egg production (\%) & $65.0^{\mathrm{a}}$ & $64.2^{\mathrm{a}}$ & $51.3^{\mathrm{b}}$ & $45.5^{\mathrm{c}}$ & 4.83 \\
Average egg weight (g) & $60.0^{\mathrm{a}}$ & $57.8^{\mathrm{b}}$ & $57.1^{\mathrm{c}}$ & $56.7^{\mathrm{c}}$ & 0.74 \\
Egg mass/hen (kg) & $10.9^{\mathrm{a}}$ & $10.4^{\mathrm{a}}$ & $8.24^{\mathrm{b}}$ & $7.25^{\mathrm{c}}$ & 0.87 \\
Egg mass production per hen/d (g) & $38.9^{\mathrm{a}}$ & $37.2^{\mathrm{a}}$ & $29.5^{\mathrm{b}}$ & $25.9^{\mathrm{c}}$ & 3.10 \\
Total feed intake/hen (kg) & $27.8^{\mathrm{a}}$ & $27.4^{\mathrm{a}}$ & $24.6^{\mathrm{b}}$ & $24.4^{\mathrm{b}}$ & 0.90 \\
Feed intake/hen/d (g) & $99.5^{\mathrm{a}}$ & $97.7^{\mathrm{a}}$ & $87.9^{\mathrm{b}}$ & $87.3^{\mathrm{b}}$ & 3.20 \\
FCR (kg feed/kg egg mass) & $2.55^{\mathrm{a}}$ & $2.63^{\mathrm{b}}$ & $2.99^{\mathrm{c}}$ & $3.37^{\mathrm{d}}$ & 0.19 \\
\hline
\end{tabular}

$\overline{a, b, c}$ Means with different superscript letters across treatment diets are significant $(p<0.05)$

$\mathrm{SEM}=$ standard error of the mean; $\mathrm{FRC}=$ feed conversation ratio 


\subsection{Fertility and hatchability of eggs}

Fertility of eggs was greater $(\mathrm{p}<0.05)$ for T1 and T2 than T3 and T4 diets (Table 5). Hens reared in T3 and T4 diets had similar values in the proportion of fertile eggs. Hatchability of eggs from the eggs set also followed similar pattern to that of fertility being higher $(\mathrm{p}<0.05)$ in hens fed with T1 and T2 diets than that of T3 and T4 which had similar values. No significant difference was observed among the first three treatment groups (T1, T2 and T3) in hatchability from fertile eggs. However, hens fed with T4 diet had lower $(p<0.05)$ value in hatchability of fertile eggs than the rest of the other treatments.

Table 5. Fertility and hatchability (\%) of eggs collected from the experimental diets

\begin{tabular}{llllll}
\hline Parameters & T1 & T2 & T3 & T4 & SEM \\
\hline Fertility of eggs after candling & $92.8^{\mathrm{a}}$ & $88.6^{\mathrm{a}}$ & $79.7^{\mathrm{b}}$ & $76.5^{\mathrm{b}}$ & 3.79 \\
Hatchability from total eggs set & $76.6^{\mathrm{a}}$ & $74.8^{\mathrm{a}}$ & $71.9^{\mathrm{b}}$ & $69.7^{\mathrm{b}}$ & 1.53 \\
Hatchability from fertile eggs & $80.5^{\mathrm{a}}$ & $81.6^{\mathrm{a}}$ & $79.8^{\mathrm{a}}$ & $74.4^{\mathrm{b}}$ & 1.60 \\
\hline
\end{tabular}

a,b,c Means with different superscript letters across treatment diets are significant $(p<0.05)$

$\mathrm{SEM}=$ standard error of the mean

\section{Discussion}

\subsection{Feed utilization and egg production}

The present findings indicated that the analyzed CP content of GMP was higher than reported for wheat bran (212 vs. $163 \mathrm{~g} / \mathrm{kg} \mathrm{DM}$ ) (Melesse et al. 2019). The high level of CP in GMP might be due to the presence of milling feed by-products that have been produced from protein rich grains.

The variations in CF content across treatment diets could be due to the presence of different constituents of the GMP, type of milling machine, and climate variation. The EE content of GMP in T1 appeared to be slightly higher than required for layer hens (NRC 1994), which could be attributed to the high proportion of fish meal which had the highest fat content after the roasted soybean seed.

Feed intake of chickens considerably reduced with increased levels of GMP. The low feed intake in T3 and T4 could be possibly be attributed to relatively high levels of CF due to increased proportion of GMP and cotton seed cake in the treatment diets. Dietary fiber has been traditionally considered as diluents of the diet and, often, an anti-nutritional factor. However, moderate amounts of fiber might improve the development of organs, enzyme production, and nutrient digestibility in poultry. Some of these effects are a consequence of better gizzard function, with an increase in gastroduodenal refluxes that facilitate the contact between nutrients and digestive enzymes (Mateos et al. 2012). These effects often result in improved growth and animal health, but the potential benefits depend largely on the physicochemical characteristics of the fiber source. On the other hand, it should be noted that higher levels of CF in layer's ration might affect the normal feed consumption resulting in reduced production performance of chicken (Varastegani and Dahlan, 2014). Moreover, high levels of dietary fiber may increase digestible energy loss, reduce mineral utilization, and negatively affect the performance of birds (GonzálezAlvarado et al. 2007). In this regard, Mateos et al. (2012) reported that the effects of dietary fiber are related to its physiochemical characteristics, inclusion levels, feed physical form, and animal species and class.

To the author's knowledge, there are no reports on the performance of layer hens fed with milling feed byproducts produced from a combination of different grains. Most works have reported on the utilization of milling by-products from a single grain such as wheat, maize, or rice bran in various farm animals (Boros et al., 2004; Farooq et al. 2011; Maina et al. 2013; Martínez et al. 2015).

Consistent to our findings, Aliakbarpour et al. (2004) reported that increase in the level of broken rice substitution significantly decreased feed intake. It also decreased body weight and FCR of experimental groups though the effects were not significant. In another study, Maina et al. (2013) reported that layer hens fed on the commercial layer diet and the maize soybean diet gained more body weight and produced more eggs than those fed on test diets based on rice milling by-products. Nevertheless, when economic returns were considered for the same, it was found that gross margins were higher with rice milling by-products based diets than with the commercial based diets.

Egg weight is one of the important phenotypic traits that influence egg quality and reproductive efficiency of the chicken parents (Melesse et al. 2011). The observation of the current study indicated that chickens fed on increased GMP levels had lower hen-housed and egg weight than those chickens reared on control diet without affecting their liveability. In good agreement with the present findings, Cho et al. (2004) reported that increasing levels of dried leftover food in the diet of layer hens decreased egg weight and egg mass compared to control diets. Reduction in the weight of eggs, percentage of the egg production and reduced feed intake in the treatment groups might be attributed to the poor quality of nutrients supplied by the GMP particularly that of essential amino acids. There is no information available in the literature on the amino acid composition of GMP. It has been reported that grain-based by-products are typically high in non-starch polysaccharides, which are poorly utilized in poultry and are low in metabolizable energy (Melesse et al. 2019). It might also be due to the presence of other unidentified anti-nutritional factors in GMP that might have resulted in general performance depression among the 
experimental hens fed with increased levels of milling feed by-products. Apart from this, the reduced feed intake in T3 and T4 diets might have negatively affected the egg production potential of experimental birds.

Hascik et al. (2010) reported that a low FCR (g feed/g gain) is a good indication of high quality feed with least cost benefit for poultry producers. The finding of this study showed that chickens reared on the control diet had comparatively a lower FCR than those fed with the treatment diets. This indicates that hens in the control diet had efficiently converted the feed they consumed into egg products. Contrary to the present findings, Farooq et al. (2011) reported that FCR in broiler chicken had improved on dietary replacement of 25, 50, 75 and $100 \%$ of maize with broken rice. Similarly, Bala et al. (2017) reported a lower FCR in broiler chickens fed with the experimental diet containing $50 \%$ and $75 \%$ maize replacement with a mixture of pearl millet and broke rice than those fed with the control diet.

\subsection{Fertility and hatchability of eggs}

Fertility and hatchability are two major parameters that highly influence the supply of day-old chicks. Many factors of which nutrition, sex ratio, age, egg weight and storage duration are the most important ones could affect fertility and hatchability of eggs (Praes et al. 2014; Uğurlu et al. 2017). For the hatchability traits, breed has little effect on hatchability of poultry eggs, although light breeds like White Leghorn have been reported to have high fertility and hatchability (King'ori 2011).

The observed low fertility and hatchability of eggs in T3 and T4 diets might be attributed to the increased intake of the anti-nutritional substance gossypol from relatively high level of cotton seed cake in both treatment diets. It has been reported that gossypol has anti-fertility effects in cocks by damaging the germinal epithelium that would lead to a reduced sperm production. It also decreased sperm motility due to specific mitochondrial damage in spermatozoa tail (Randel et al. 1992). Another possible explanation for reduced fertility and hatchability values with increased levels of GMP could be the CP content of the experimental diets. Hocking \& Bernard (1997) and Graaf et al. (2018) reported that broiler breeder males fed 12\% CP had higher sperm concentration than those fed on 16\% CP diet. Similarly, Uğurlu et al. (2017) reported that fertility and hatchability rate of total eggs in pheasants tended to decrease with increasing levels of CP in the diet. In the present study, cocks were fed with the same diet of the hens that had high levels of CP than their requirements (13-14\% vs. 18.3-18.7\%). Moreover, although diets were formulated to be iso-nitrogenous, the CP content of T3 and T4 diets was slightly higher than that of $\mathrm{T} 1$ and $\mathrm{T} 2$.

Early studies conducted by Daghir \& Shah (1973) and Patel \& McGinnis (1977) reported that excess dietary protein in layer hens increased the requirement of Vitamin A, Biotin, Vitamin B12 and calcium that negatively influenced the hatchability of eggs. On the other hand, Vo et al. (1994) reported higher hatchability in brown-egg layers fed with high protein diets. It is thus difficult to establish specific effects of maternal dietary energy intake on fertility and hatchability.

Wilson et al. (1980) found that broiler breeders on litter floor had normal hatchability with $0.31 \%$ phosphorus in their diets, which implies that birds on litter floors appear to recycle considerable amounts of phosphorus by coprophagy. Thus, excess phosphorus intake through a combination of dietary $(0.44 \%$ in T3 and $0.45 \%$ in T4) and coprophagic sources might have reduced the shell quality and, indirectly, decreased the hatchability of the eggs.

\section{Conclusion}

The grain milling by-products (GMP) had moderately high protein and ash contents. The hen-housed and daily egg mass egg production and feed intake was significantly higher in hens fed with the control diet (T1) and with $10 \%$ substituted maize by GMP (T2) group than those reared with 15\% (T3) and 20\% (T4) GMP replaced diets. No significance difference was observed in these parameters among hens fed with $\mathrm{T} 1$ and $\mathrm{T} 2$ diets. The feed conversion ratio ( $\mathrm{kg}$ feed/ $\mathrm{kg}$ egg mass) was significantly lower in hens fed with $\mathrm{T} 1$ and $\mathrm{T} 2$ diets than the rest of the treatment groups. Fertility and hatchability of eggs was significantly greater for chickens fed with the control and T2 diets. The substitution of maize grain with increased levels of GMP significantly reduced most of the performance parameters. However, the substitution of maize with $10 \%$ had similar effect with that of the control group in all parameters and could be recommended as a viable substitution option. However, considering the advantage of reducing high costs of maize grain a substitution rate of $15 \%$ and perhaps higher could be justifiable under smallholder production settings. Thus, using inexpensive and easily accessible grain milling by-products in the layer rations presents a positive alternative to substitute the relatively expensive maize grain in layer rations.

Suggested future works include testing the effect of substitution of maize with various levels of grain milling byproducts on egg quality parameters (both external and internal) in layer hens. Future research is also recommended to investigate the substitution effect of maize or other conventional feed resources with grain milling byproducts on the growth performance and carcass traits of broiler chickens along with cost benefit analysis.

\section{Acknowledgments}

The author gratefully acknowledges the financial support received from FARM Africa. The author further 
acknowledges the Animal Nutrition Laboratory at Holleta Agricultural Research Center for their kind collaboration to analyze the feed ingredients. Moreover, the assistance received from Dr. Mohammed Beyan to follow-up the research activity in the absence of the researcher is highly appreciated.

\section{References}

Aliakbarpour, H., Ghodratnama, A., Kamyab, A. \& Gujegh, D. (2004). The effect of dietary broken rice substitution in corn on broiler's performance. Agricultural Research, 4 (1): 25-35.

AOAC. (2005). Association Official Analytical Chemists, Official Methods of Analysis. $18^{\text {th }}$ edition. Washington D.C, USA.

Bala, S., Sharma, R. K., Khan, N., Rastogi, A. \& Haq, Z. (2017). Performance of broiler chicken as affected by replacement of maize with pearl millet and broken rice mixture in the diet. Indian Journal of Animal Nutrition, 34 (4): 437-446. doi: 10.5958/2231-6744.2017.00070.6.

Boros, D., Slominski, B. A., Guenter, W., Campbell, L. D. \& Jones, O. (2004). Wheat by-products in poultry nutrition. Part II. Nutritive value of wheat screenings, bakery by-products, wheat mill bran, \& their improved utilization by enzyme supplementation. Canadian Journal of Animal Science, 84: 429-435.

Cho Y.M., Shin I. S. \& Yang, C. J. (2004). Effects of feeding dried leftover food on productivity of laying hens. Asian-Australian Journal of Animal Science, 17 (4): 518-522.

Daghir, N. J., \& Shah, M. A. (1973). Effect of dietary protein level on vitamin B6 requirement of chicks. Poultry Science, 52: 1247-1252.

Farooq, J., Sharma, R.K. \& Kuma,r V. (2011). Evaluation of broken rice as maize replacer in broiler ration. Indian Veterinary Journal, 88: 50-52.

González-Alvarado, J.M., Jiménez-Moreno, R. \& Mateos G.G. (2007). Effects of type of cereal, heat processing of the cereal, and inclusion of fiber in the diet on productive performance and digestive traits of broilers. Poultry Science, 86(8): 1705-1715.

Graaf, B., Ciacciariello, M. \& Tyler, N.C. (2018). The effect of crude protein intake on sperm quality of young and old male broiler breeders. South African Journal of Animal Science, 48 (6). http://dx.doi.org/10.4314/sajas.v48i6.9.

Hascik, P., Kacaniova, M., Mihok, M., Pochop, J. \& Benczova, E. (2010). Performance of various broiler chicken hybrids fed with commercially produced feed mixtures. International Journal of Poultry Science, 9 (11): 1076-1082.

Hocking, P.M. \& Bernard, R. (1997). Effects of dietary crude protein content and food intake on the production of semen in two lines of broiler breeder males. British Poultry Science, 38: 199-02.

King'ori, A.M. (2011). Review of the factors that influence egg fertility and hatchability in poultry. International Journal of Poultry Science, 10(6): 483-492.

Maina, J.G., Kamau, W.N. \& Kabuage, L.W. (2013). Evaluation of high levels of rice milling byproducts in chicken layer diets: effects on layer performance, egg quality and economic returns. Livestock Research for Rural Development, 25, Article \#119. Retrieved April 17, 2020, from http://www.lrrd.org/lrrd25/7/main25119.htm.

Martínez, Y., Carrión, Y., Rodríguez, R., Valdivié, M., Olmo, .C, Betancur, C. \& Liu, G. (2015). Growth performance, organ weights and some blood parameters of replacement laying pullets fed with increasing levels of wheat bran. Brazilian Journal of Poultry Science, 17 (3): 347-354.

Mateos, G., Jiménez-Moreno, E., Serrano, M.P. \& Lázaro, R. (2012). Poultry response to high levels of dietary fiber sources varying in physical and chemical characteristics. Journal of Applied Poultry Research 21(10): $156-174$

Melesse, A., Maak, S., Schmidt, R. \& von Lengerken, G. (2011). Effect of long-term heat stress on some performance traits and plasma enzyme activities in Naked-neck chickens and their F1 crosses with commercial layer breeds. Livestock Science, 141: 227-231.

Melesse, A., Getye, Y., Berihun, K. \& Banerjee, S. (2013). Effect of feeding graded levels of Moringa stenopetala leaf meal on growth performance, carcass traits and some serum biochemical parameters of Koekoek chickens. Livestock Science, 157: 498-505.

Melesse, A. (2014). Significance of scavenging chicken production in the rural community of Africa for enhanced food security. World's Poultry Science Journal, 70: 593-606.

Melesse, M., Ganebo, G., Abebe, A. (2019). Substitution effect of noug seed (Guzoitia abyssinica) cake with various levels of samma (Urtica simensis S.) leaf meal on egg production and egg quality parameters of commercial layer hen. Iranian Journal of Applied Animal Science, 9 (4): 727-735.

NRC. (1994). Nutrient Requirements of Poultry. National Research Council, $9^{\text {th }}$ rev. ed. Natl. Acad. Press, Washington, DC, USA.

Patel, M. B. \& McGinnis, J. (1977). The effect of levels of protein and vitamin B12 in hen diets on egg production and hatchability of eggs and on livability and growth of chicks. Poultry Science, 56: 45-53. 
Praes, M.F.F.M., Junqueira, O.M., Pereira, A.A., Filardi, R.S., Duarte, K.F., Sgavioli S., Alva J.C.R. \& Dominiques C.H.P. (2014). High-fiber diets with reduced crude protein for commercial layers. Brazilian Journal of Poultry Science, 16(2): 43-50.

Randel, R.D., Chase, C. C. Jr \& Wyse S. J. (1992). Effects of gossypol and cottonseed products on reproduction of mammals. Journal of Animal Science, 70: 1628-1638.

Rocha, C., Durau, J. F., Barrilli, L. N. E., Dahlke, F., Maiorka, P., \& Maiorka, A. (2014). The effect of raw and roasted soybeans on intestinal health, diet digestibility, and pancreas weight of broilers. Applied Poultry Research, 23:71-79. http://dx.doi.org/ 10.3382/japr.2013-00829.

SAS. (2012). Statistical Analysis Systems (ver. 9.4). SAS/STAT User's Guide. SAS Institute Inc., Cary, NC.

Shapiro, B.I., Gebru, G., Desta, S., Negassa, A., Nigussie, K., Aboset, G. \& Mechal, H. (2015). Ethiopia livestock master plan. ILRI Project Report. Nairobi, Kenya: International Livestock Research Institute (ILRI).

Uğurlu, M., Akdağ, F., Teke, B. \& Salman, M. (2017). Effects of protein in diet and sex ratio on egg production, egg and hatching chick weight, fertility, hatchability and embryonal mortality in pheasants (Phasianus colchicus). Brazilian Journal of Poultry Science, 19 (2): 231-238.

Van Soest, P.J., Robertson, J.B. \& Lewis, B.A. (1991). Methods of dietary fiber, neutral detergent fiber, and nonstarch polysaccharides in relation to animal nutrition. Journal of Dairy Science, 74: 3583-3597.

Varastegani, S. \& Dahlan, G. (2014). Influence of dietary fiber levels on feed utilization and growth performance in poultry influence of dietary fiber levels on feed utilization and growth performance in poultry. Journal of Animal Production Advance, 4(6): 422-429.

Vo, K. V., Adefope, N. A., \& Wakefield, T. (1994). Effect of dietary protein restriction and sulfur amino acid supplementation on reproductive efficiency of brown-egg type layers. Poultry Science, 73 (Suppl. 1):163. (Abstr.)

Wilson, H. R., Miller, E. R., Harms, R. H., \& Damron, B. L. (1980). Hatchability of chicken eggs as affected by dietary phosphorus and calcium. Poultry Science, 59:1284-1289.

Wilson, H. R. (1997). Effects of maternal nutrition on hatchability. Poultry Science, 76:134-143. 